\title{
Digestibility and amino acid composition of digesta at the end of the ileum in preruminant calves fed soyabean protein
}

\author{
I Caugant 1, R Toullec 1,*, M Formal 1, P Guilloteau 1, L Savoie 2 \\ 1 INRA, Laboratoire du Jeune Ruminant, 65, rue de Saint-Brieuc, 35042 Rennes Cedex, France; \\ 2 Département de Nutrition Humaine et de Consommation, Faculté des Sciences de l'Agriculture \\ et de l'Alimentation, Université Laval, Ste-Foy, Québec G1K 7P4, Canada
}

(Received 24 February 1993; accepted 8 June 1993)

\begin{abstract}
Summary - The ileal digestion of 3 milk substitutes in which skim milk powder was either the only protein source (control diet) or was partially replaced $(50 \%)$ by a heated soyabean flour (SF diet) or an alcohol-treated soyabean protein concentrate (SC diet) was studied in 6 preruminant calves which were fitted with an ileo-cæcal re-entrant cannula. The apparent digestibility of total nitrogen and amino acids was lower with the SF and SC diets than with the control diet $(0.89,0.89$ and 0.94 , respectively, for amino acid nitrogen). Assuming that true digestibility was complete with the control diet, the values were lower with the SF and SC diets, especially for cystine, threonine, valine, isoleucine, leucine and histidine. With the SF and SC diets, digesta contained more aspartic acid and glutamic acid but less threonine, sulfur amino acids, lysine, serine and alanine than with the control diet. The additional undigested fractions obtained with the SF and SC diets compared to the control diet were rich in aspartic and glutamic acids, and poor in arginine, suggesting that partially degraded dietary fractions different from the whole soyabean escaped digestion in the small intestine; these fractions probably originated mainly from glycinin. No significant differences were observed between the 2 soyabean diets.
\end{abstract}

digestion / preruminant calf / soyabean / protein / amino acid

Résumé - Digestibilité et composition en acides aminés des digesta à la fin de l'iléon chez le veau préruminant recevant des protéines de soja. La digestion iléale de trois laits de remplacement dans lesquels la poudre de lait écrémé était la seule source de protéines (régime témoin) ou avait été partiellement $(50 \%)$ remplacée par du tourteau de soja cuit (régime SF) ou du concentrat protéique de soja (régime SC) a été étudiée chez 6 veaux préruminants munis d'une canule iléocæcale réentrante. La digestibilité apparente de l'azote total et des acides aminés a été moins élevée avec les régimes $S F$ et $S C$ qu'avec le régime témoin (respectivement $0,89,0,89$ et 0,94 pour l'azote des acides aminés). En considérant que la digestibilité des protéines de lait était totale, les digestibilités vraies des acides aminés étaient moins élevées avec les régimes $S F$ et $S C$ qu'avec le régime témoin, principalement pour la cystine, la thréonine, la valine, lisoleucine, la leucine et l'histi-

" Correspondence and reprints 
dine. Avec les régimes SF et SC, les digesta ont été plus riches en acides aspartique et glutamique et moins riches en thréonine, acides aminés soufrés, lysine, sérine et alanine. Les suppléments d'indigéré obtenus avec les régimes $S F$ et $S C$ par rapport au régime témoin se sont caractérisés par des teneurs élevées en acides aspartique et glutamique et basses en arginine, suggérant que des fractions particulières des protéines de soja, provenant probablement en majeure partie de la glycinine, ont échappé à la digestion dans l'intestin grêle. Aucune différence significative n'a été observée entre les régimes SF et SC.

digestion / veau préruminant / soja / protéines / acides aminés

\section{INTRODUCTION}

Replacement of milk protein with alternative protein sources in milk substitutes for preruminant calves is of great interest because of the high cost of milk proteins. However, substitute proteins such as pea (Nunes do Prado et al, 1989; Bush et al, 1992), fish (Campos et al, 1982; Guilloteau et al, 1986) and soyabean (Campos et al, 1982; Guilloteau et al, 1986; Silva et al, 1986; Dawson et al, 1988) result in reduced apparent digestibility and liveweight gain (Nitsan et al, 1971; Akinyele and Harshbarger, 1983). Replacement protein sources have induced faster gastric emptying (Caugant et al, 1992) and can decrease digestive secretions (Williams et al, 1976).

Soyabean protein is often used in calf milk replacers because of its low cost and its content in essential amino acids (AA) which is close to that of cow's milk. However, insufficiently processed soyabean contains anti-nutritional factors such as protease inhibitors, lectins and allergenic proteins which could explain the poor digestibility of products containing soyabean (Huisman and Jansman, 1991). Protein concentrates and isolates have provided better results than flours (Akinyele and Harshbarger, 1983; Dawson et al, 1988). Treatment with hot aqueous ethanol has improved soyabean protein utilization (Sissons et al, 1979; Silva et al, 1986).
This study was conducted to determine the effect of partial replacement $(50 \%)$ of skim milk powder by 2 differently processed soyabean products (a heated flour or an alcohol-treated protein concentrate) on the ileal digestion of the milk substitute in preruminant calves. The AA composition of ileal digesta was compared with that of dietary, endogenous and bacterial protein in order to estimate the origin of undigested protein.

\section{MATERIAL AND METHODS}

\section{Diets}

Two milk substitutes (SF and SC) and a control diet were prepared. Protein in the control diet came exclusively from spray-dried skim-milk powder. In the other 2 diets, $50 \%$ of the protein was provided by a soyabean flour (SF diet) or a soyabean protein concentrate (SC diet), the remainder being supplied by skim milk powder. The composition of the control and milk substitute diets is given in table I. Each diet contained $\approx 22 \%$ protein (dry matter (DM) basis).

The soyabean flour (Société Industrielle des Oléagineux, France) was obtained from the seed by dehulling, lipid extraction with hexane and heat treatment in order to denature the protease inhibitors (Di Pietro and Liener, 1989). The soyabean protein concentrate (Aarhus Oliefabrik, Denmark) was obtained by oligoside extraction and heat treatment with hot aqueous ethanol which inactivates the antigenic factors of soyabean (Sissons et al, 1979). These protein 
sources contained 49 and $67 \%$ protein (DM basis) respectively. Glycinin and $\beta$-conglycinin, which are considered to be involved in the allergenic effects of soyabean products (Kilshaw and Sissons, 1979) were still present in immunoreactive form in the soyabean flour (12 and $1 \%$ respectively of total protein), but were no longer detectable in the soyabean concentrate (Tukur et al, unpublished results). By contrast, $\alpha$ conglycinin, which does not appear to be antigenic when given orally to calves, was present in similar immunoreactive amounts in both soyabean products $(0.2 \%$ total protein). The amino acid compositions of the protein sources and of the diets are given in table II.

\section{Animals and feeding}

Six Holstein male calves ranging in age from 2 to 3 months and weighing $\approx 100 \mathrm{~kg}$ were fitted with a catheter in the abomasum and a reentrant cannula with the proximal part inserted at the distal ileum and the distal part in the cæcum (Guilloteau et al, 1986). The calves received 2 meals daily (at 8 h 30 and 16 h 30) by infusion of the diet into the abomasum through the abomasal catheter. The total DM rate was

Table I. Composition of the diets.

\begin{tabular}{ll}
\hline Ingredient (\% powder) & \multicolumn{1}{c}{ Diet } \\
\cline { 2 - 2 } & Control SF SC \\
\hline
\end{tabular}

$\begin{array}{lrrr}\text { Fat premix } & 50 & 50 & 50 \\ \text { Skim milk powder } & 32 & - & - \\ \text { Soyabean flour } & - & 24 & - \\ \text { Soyabean protein concentrate } & - & - & 17 \\ \text { Lactose } & 12.6 & 19.0 & 26.0 \\ \text { Starch } & 3.0 & 3.0 & 3.0 \\ \text { DL-Methionine } & 0.08 & 0.08 & 0.08 \\ \text { Vitamins and minerals } & 2.37 & 3.95 & 3.90\end{array}$

Fat premix: $64 \%$ skim milk powder and $36 \%$ tallow (LACTEL, PQ, Canada) ; control diet: skim milk powder; SF diet: skim milk powder mixed with soyabean flour (50:50 on a CP basis); SC diet: skim milk powder mixed with soyabean protein concentrate (50:50 on a CP basis). set at $58 \mathrm{~g} /(\mathrm{kg} \text { body weight) })^{0.75}$ per day. Two wk post-surgery, each calf received each experimental diet for $2 \mathrm{wk}$, according to a double Latin square design.

\section{Collection of digesta}

During the second week, total ileal digesta flowing from the proximal part of the cannula were collected from each animal for $4 \mathrm{~d}$. Digesta were collected in flasks containing sodium benzoate (10 g/kg digesta) to limit microbial activity. Digesta were weighed every day and aliquots from the 4-d collection were frozen for subsequent freeze-drying and chemical analysis.

\section{Chemical analysis}

Samples of the 3 diets, soyabean flour and soyabean protein concentrate, and freeze-dried ileal digesta were analysed for DM, nitrogen (N) and AA. Dry matter was determined by drying in an oven at $105^{\circ} \mathrm{C}$ for $16 \mathrm{~h}$. Nitrogen was measured using the Kjeldahl method. AA composition was determined by ion exchange chromatography after acid hydrolysis of the samples in $6 \mathrm{~N}$ $\mathrm{HCl}$ at $110^{\circ} \mathrm{C}$ for 24 and $48 \mathrm{~h}$; the $24-\mathrm{h}$ hydrolysis period was sufficient for most $A A$, but the longer 48-h period was necessary for valine and isoleucine (Prugnaud and Pion, 1976). Before acid hydrolysis, oxidation with performic acid was carried out to determine sulphur AA. AA determination was carried out using a PharmaciaLKB analyser (Alpha + system, Sweden).

\section{Statistical analysis}

Results were submitted to a variance analysis and means ranked according to Sheffe's test. Significance was declared at $P \leq 0.05$. The AA compositions of proteins were compared 2 by 2 calculating the $\chi^{2}$ distance (Guilloteau et al, 1983). The $\chi^{2}$ distance between 2 proteins $i$ and $j$ was calculated as follows:

$$
\begin{gathered}
k=17 \\
\chi^{2}=17 \sum_{k=1}(A A i k-A A j k)^{2} /((A A i k+A A j k) / 2) \\
k=1
\end{gathered}
$$


Table II. Amino acid composition (\% of assayed AA) of the protein sources and diets.

\begin{tabular}{|c|c|c|c|c|c|}
\hline & \multicolumn{2}{|c|}{ Protein source } & \multicolumn{3}{|c|}{ Diet } \\
\hline & $\begin{array}{l}\text { Soyabean } \\
\text { flour }\end{array}$ & $\begin{array}{l}\text { Soyabean protein } \\
\text { concentrate }\end{array}$ & Control & $S F$ & SC \\
\hline ASP & 12.28 & 12.53 & 7.87 & 10.00 & 9.74 \\
\hline THR & 3.97 & 3.87 & 4.19 & 4.02 & 3.95 \\
\hline SER & 5.37 & 5.15 & 5.49 & 5.42 & 5.28 \\
\hline GLU & 19.37 & 19.68 & 21.41 & 20.51 & 20.74 \\
\hline PRO & 5.15 & 5.49 & 9.56 & 7.24 & 7.57 \\
\hline GLY & 4.35 & 4.11 & 1.81 & 3.09 & 2.86 \\
\hline ALA & 4.46 & 4.11 & 3.08 & 3.78 & 3.55 \\
\hline CYS & 1.41 & 1.60 & 0.74 & 1.18 & 1.12 \\
\hline VAL & 5.01 & 4.61 & 6.16 & 5.55 & 5.42 \\
\hline MET & 1.41 & 1.98 & 2.34 & 2.03 & 2.51 \\
\hline ILE & 4.49 & 4.12 & 4.85 & 4.69 & 4.51 \\
\hline LEU & 8.00 & 7.85 & 9.71 & 8.85 & 9.00 \\
\hline TYR & 3.40 & 3.70 & 4.46 & 3.97 & 4.24 \\
\hline $\mathrm{PHE}$ & 5.27 & 5.31 & 4.95 & 4.99 & 4.98 \\
\hline HIS & 2.45 & 2.46 & 2.52 & 2.43 & 2.47 \\
\hline LYS & 6.25 & 6.36 & 7.69 & 6.94 & 7.20 \\
\hline ARG & 7.35 & 7.08 & 3.15 & 5.29 & 4.86 \\
\hline$\sum \mathrm{AA}(\mathrm{g} / 16 \mathrm{~g} \mathrm{~N})$ & 109.03 & 95.29 & 112.05 & 106.62 & 105.61 \\
\hline AAN (\% total $N)$ & 92.80 & 80.45 & 88.27 & 85.43 & 83.06 \\
\hline
\end{tabular}

Control diet: skim milk powder; SF diet: skim milk powder mixed with soyabean flour (50:50 on a CP basis) ; SC diet: skim milk powder mixed with soyabean protein concentrate (50:50 on a CP basis) ; N: nitrogen ; $\Sigma A A$ : sum of assayed AA ; AAN: $N$ of assayed AA except amid- $N$ of asparagine and glutamine.

where $A A i k$ and $A A j k$ are the respective percentages of $A A k$ in the sum of the assayed AA in the proteins $i$ and $j ; k$ represents the different $A A$ and varies between 1 and 17 . As the $\chi^{2}$ distance decreases, similarity between the proteins increases.

The proportions of dietary, endogenous and bacterial proteins which could be the main constituents of digesta protein were assessed by the method developed by Duvaux et al (1990). This method uses a multiple regression analysis to establish the theoretical mixture which minimizes the $\chi^{2}$ distance with regard to the AA composition of digesta. The mean composition of axenic lamb faeces (Combe, 1976) and calf meconium (Grongnet et al, 1981) was used as a model of undigested endogenous protein. The mean composition of pig (Mason et al, 1976) and sheep (Mason, 1979) fæcal bacteria was used to represent the composition of gut bacteria. The common protein escaping digestion in the small intestine of calves given diets based on milk, fish or soyabean protein (Guilloteau et al, 1986), was used as a model of the mixture of undigested endogenous and bacterial proteins. Reference AA compositions of soyabean proteins were those of major globulins: glycinin (Okubo et al, 1969), $\beta$-conglycinin (Koshiyama, 1968) and the acid subunits of glycinin (Moreira et al, 1979). 


\section{RESULTS}

Health conditions were generally satisfactory. The cannulae remained functional during the trial.

\section{Ileal apparent digestibility}

The ileal apparent digestibility of DM was higher for the control than for the SF and SC diets $(0.88,0.80$ and 0.83 , respectively) but the difference was not significant.
Digestibility of organic matter $(0.90,0.82$ and 0.85 with the control, SF and SC diets, respectively) differed between the control and the SF diet. The values were slightly higher for the SC than for the SF diet.

The ileal apparent digestibility of $N$ was lower with the soyabean than with the control diet (table III). Differences were significant between the control and the SF diet, with an intermediate digestibility for the SC diet. The apparent digestibility was always higher for total AAN than for total $\mathrm{N}$; differences were $0.035,0.044$ and 0.018 for the control, SF and SC diets, respectively. Irre-

Table III. lleal digestibilities of $\mathrm{N}$ and assayed $\mathrm{AA}$ : apparent (mean $\pm \mathrm{SE}$ ) and true values.

\begin{tabular}{|c|c|c|c|c|c|}
\hline \multicolumn{2}{|c|}{ Digestibility } & \multicolumn{2}{|l|}{ Apparent } & \multicolumn{2}{|c|}{ True * } \\
\hline Diet & Control & $S F$ & $S C$ & $\begin{array}{c}\text { Soyabean } \\
\text { flour }\end{array}$ & $\begin{array}{l}\text { Soyabean } \\
\text { concentrate }\end{array}$ \\
\hline Total N & $0.904 \pm 0.022 \mathrm{~A}$ & $0.851 \pm 0.041 B$ & $0.870 \pm 0.044 \mathrm{AB}$ & 0.892 & 0.924 \\
\hline AAN & $0.939 \pm 0.006 \mathrm{~A}$ & $0.885 \pm 0.013 B$ & $0.888 \pm 0.014 \mathrm{~B}$ & 0.907 & 0.908 \\
\hline ASP & $0.930 \pm 0.007 \mathrm{~A}$ & $0.846 \pm 0.016 \mathrm{~B}$ & $0.852 \pm 0.023 \mathrm{~B}$ & 0.847 & 0.851 \\
\hline THR & $0.882 \pm 0.009 \mathrm{~A}$ & $0.820 \pm 0.017 \mathrm{~B}$ & $0.813 \pm 0.016 \mathrm{~B}$ & 0.894 & 0.884 \\
\hline SER & $0.928 \pm 0.006 \mathrm{~A}$ & $0.884 \pm 0.011 B$ & $0.881 \pm 0.016 \mathrm{~B}$ & 0.922 & 0.914 \\
\hline GLU & $0.946 \pm 0.009 \mathrm{~A}$ & $0.882 \pm 0.015 B$ & $0.873 \pm 0.028 B$ & 0.877 & $0.845^{\circ}$ \\
\hline PRO & $0.961 \pm 0.003 \mathrm{~A}$ & $0.907 \pm 0.013 B$ & $0.910 \pm 0.015 B$ & 0.892 & 0.888 \\
\hline GLY & $0.826 \pm 0.016$ & $0.792 \pm 0.032$ & $0.783 \pm 0.026$ & 0.858 & 0.851 \\
\hline$A L A$ & $0.883 \pm 0.015$ & $0.840 \pm 0.025$ & $0.851 \pm 0.010$ & 0.899 & 0.924 \\
\hline CYS & $0.730 \pm 0.035$ & $0.725 \pm 0.030$ & $0.707 \pm 0.046$ & 0.837 & 0.845 \\
\hline VAL & $0.939 \pm 0.006 \mathrm{~A}$ & $0.890 \pm 0.016 \mathrm{~B}$ & $0.891 \pm 0.008 B$ & 0.913 & 0.913 \\
\hline MET ** & $0.956 \pm 0.006 \mathrm{~A}$ & $0.918 \pm 0.009 B$ & $0.942 \pm 0.005 \mathrm{AB}$ & 0.937 & 0.967 \\
\hline ILE & $0.955 \pm 0.004 \mathrm{~A}$ & $0.911 \pm 0.014 B$ & $0.918 \pm 0.006 \mathrm{AB}$ & 0.917 & 0.926 \\
\hline LEU & $0.958 \pm 0.004 \mathrm{~A}$ & $0.913 \pm 0.012 B$ & $0.923 \pm 0.006 \mathrm{~B}$ & 0.914 & 0.929 \\
\hline TYR & $0.960 \pm 0.004 \mathrm{~A}$ & $0.927 \pm 0.007 \mathrm{~B}$ & $0.932 \pm 0.007 \mathrm{~B}$ & 0.938 & 0.941 \\
\hline PHE & $0.958 \pm 0.005 \mathrm{~A}$ & $0.913 \pm 0.015 B$ & $0.926 \pm 0.006 \mathrm{AB}$ & 0.920 & 0.942 \\
\hline HIS & $0.951 \pm 0.005 \mathrm{~A}$ & $0.902 \pm 0.011 \mathrm{~B}$ & $0.905 \pm 0.012 \mathrm{~B}$ & 0.913 & 0.910 \\
\hline LYS & $0.938 \pm 0.006 \mathrm{~A}$ & $0.897 \pm 0.014 B$ & $0.908 \pm 0.009 \mathrm{AB}$ & 0.930 & 0.949 \\
\hline ARG & $0.940 \pm 0.005$ & $0.935 \pm 0.007$ & $0.941 \pm 0.004$ & 0.960 & 0.974 \\
\hline
\end{tabular}

Control diet: skim milk powder; SF diet: skim milk powder mixed with soyabean flour (50:50 on a CP basis) ; SC diet: skim milk powder mixed with soyabean protein concentrate (50:50 on a CP basis); AAN: $N$ of assayed AA except amid- $\mathrm{N}$ of asparagine and glutamine ; means with different letters are statistically different $(P<0.05)$; " values calculated assuming that the true digestibility of total milk protein was complete and that the amounts of AA per $\mathrm{kg}$ dry matter intake escaping digestion in the small intestine with the control diet corresponded to the endogenous contributions with the other diets; ${ }^{* \star}$ supplement excluded. 
spective of the diet, the digestibilities were always lower for threonine, glycine, alanine, and cystine, and higher for methionine and tyrosine than for AAN. AA digestibilities were lower with the soyabean than with the control diet. The diet digestibility could be classified in this order: control $>$ SC > SF. Differences between control and SF diets were generally significant, except for glycine, alanine, cystine and arginine. Cystine was the least digestible in the 3 diets, whereas methionine and arginine were the most digestible in the control and the soyabean diets, respectively. The differences were not significant between the SF and the SC diets, with a small tendency to be higher with the SC diet.

\section{AA composition of protein sources and ileal digesta}

The soyabean flour and the soyabean protein concentrate contained more aspartic acid, glycine, cystine and arginine, and less glutamic acid, proline, valine, leucine, tyrosine and lysine than skim milk powder (table II). Differences between SF and SC diets were small $\left(\chi^{2}=4\right)$, whereas differences between the control and the soyabean diets were higher $\left(43<\chi^{2}<62\right)$.

Irrespective of the diet, AAN represented a lower proportion of total $\mathrm{N}$ in digesta than in the diet: 58,67 and $70 \%$ instead of 88,85 and $83 \%$ respectively with the control, SF and SC diets. Digesta protein contained more aspartic acid, threonine, glycine, cystine, and less proline, leucine and phenylalanine (and arginine with the SF and $\mathrm{SC}$ diets; fig 1). The differences in AA profile between digesta and the corresponding diets or protein sources were important, as shown by the large $\chi^{2}$ distances $\left(132 \leq \chi^{2} \leq 279\right.$; table IV). The AA composition of ileal digesta was also different from that of endogenous and bacterial protein ( $\chi^{2}$ distances $\geq 109$ ). Significant differences in the proportion of aspartic acid, threonine, serine, methionine and lysine were observed in the ileal digesta between

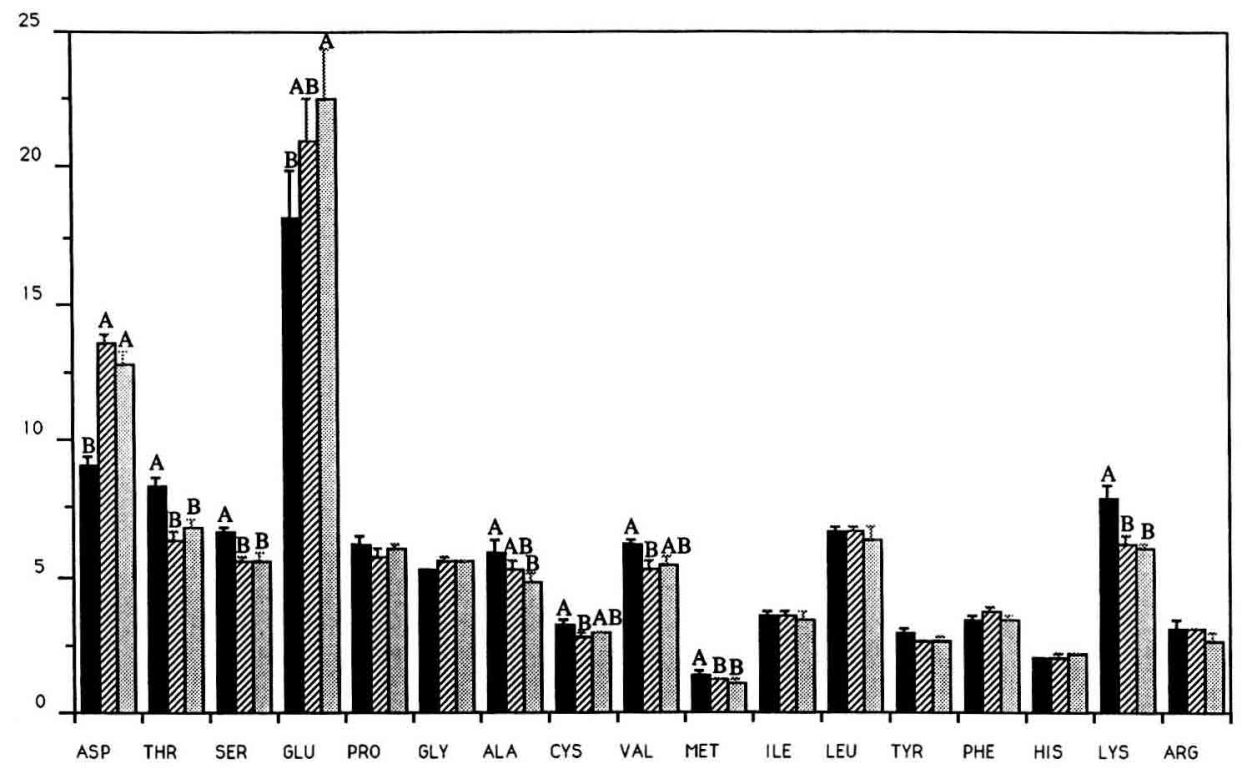

Fig 1. Amino acid composition (\% of assayed AA) of the ileal digesta with the control ( $\square$ ), $S F(\bigotimes)$ or SC ( ) diets. Vertical bars are SEs. Means with different letters are different $(P<0.05)$. 
the control and the 2 soyabean diets (fig $1)$; this was reflected by relatively high $\chi^{2}$ distances between these digesta $\left(\chi^{2}=62\right.$ and 63 compared to SF and SC, respectively; table IV). In contrast, no differences were observed between the AA composi- tion of digesta obtained with the SF and the SC diets $\left(\chi^{2}=6\right)$. However, the AA composition of the SF and SC digesta was very different from that of the major soyabean proteins and their subunits $\left(132 \leq \chi^{2}\right.$ $\leq 481$ ). Glycinin was the least different

Table IV. $\chi^{2}$ distances between ileal digesta and theoretical protein mixtures.

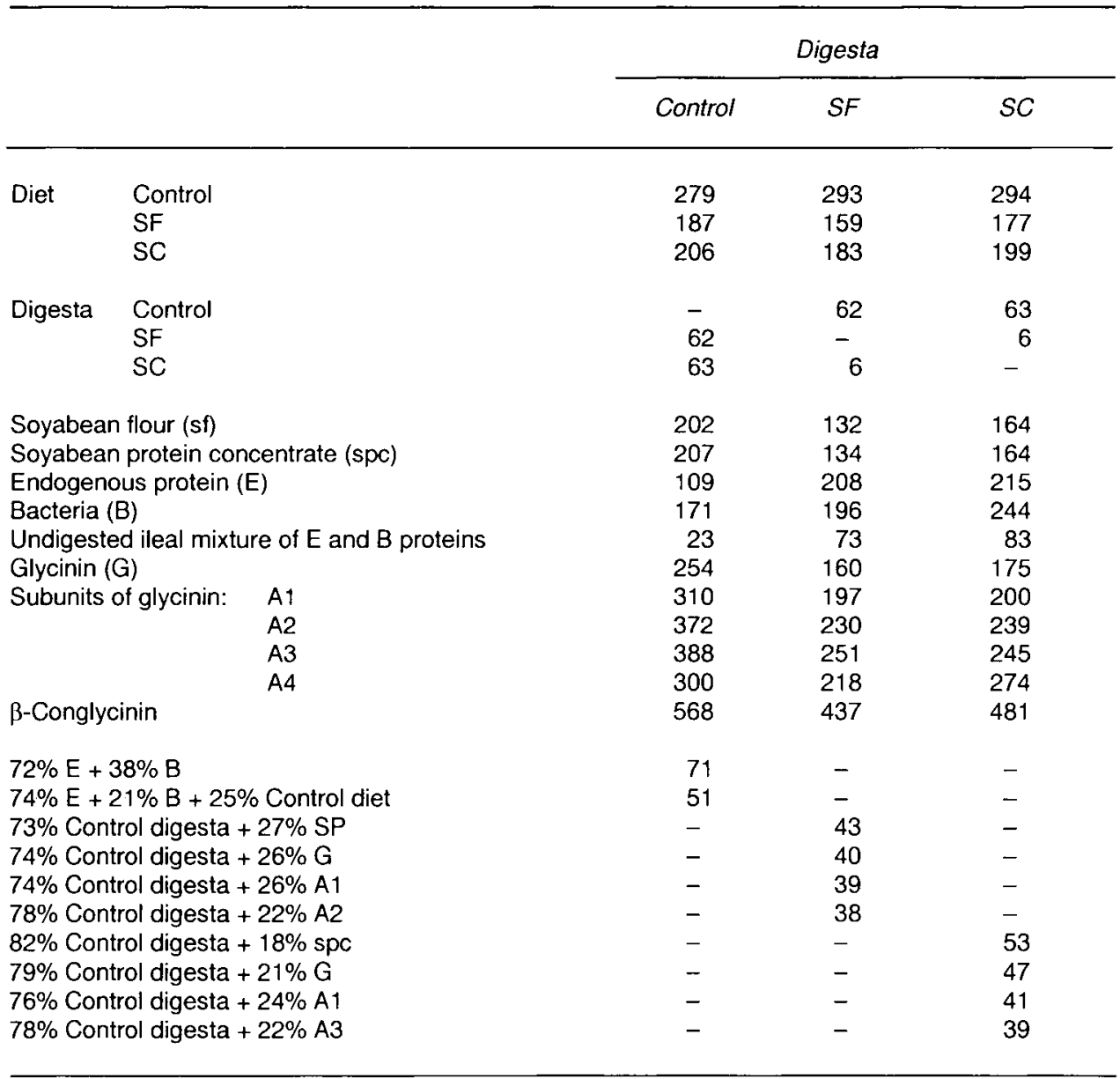

Control diet: skim milk powder; SF diet: skim milk powder mixed with soyabean flour (50:50 on a CP basis); SC diet: skim milk powder mixed with soyabean protein concentrate (50:50 on a CP basis); endogenous protein: mean composition of axenic lamb fæces (Combe et al, 1976) and calf meconium (Grongnet et al, 1981); bacteria: mean composition of pig (Mason et al, 1976) and sheep fæcal bacteria (Mason, 1979); undigested ileal mixture of $E$ and $B$ : common protein escaping digestion in calves given diets based on milk, fish or soyabean protein (Guilloteau et al, 1986); glycinin (Okubo et al, 1969); $\beta$-conglycinin (Koshiyama, 1968); subunits of glycinin (Moreira et al, 1979). 
from the SF and SC digesta, but the large $\chi^{2}$ distances (160 and 175 , respectively) showed that protein as a whole was at least diluted in the digesta.

The amounts of AA recovered in the distal ileum relative to dry matter intake are presented in table $\mathrm{V}$. The undigested amounts were always higher with the SF and SC diets than in the control diet. These amounts were higher with the SF than with the SC diets (except for glutamic acid), but the differences were never significant. The additional undigested fractions obtained with the SF and SC diets (calculated as the total amounts of AA recovered at the end of the ileum with these diets minus those obtained with the control diet) corresponded to 83 and $73 \%$, respec- tively, of the undigested AAN with the control diet. Compared to the whole dietary soyabean protein, they were richer in aspartic and glutamic acids, which represented 42 and $48 \%$ of the total AA with the SF and SC diet, respectively; in contrast, they contained less arginine and lysine. They were very different from the dietary, whole digesta, endogenous, bacterial and soyabean proteins $\left(80 \leq \chi^{2} \leq 619\right)$.

\section{DISCUSSION}

The ileal apparent digestibility was lower with the soyabean diets than with the control diet, in agreement with the results previously obtained with other soyabean prod-

Table V. Amount (mg/kg dry matter intake) of apparently undigested amino acids (mean \pm SE) and composition of the additional undigested protein (\% of assayed AA).

\begin{tabular}{|c|c|c|c|c|c|}
\hline & \multicolumn{3}{|c|}{ Diet } & \multicolumn{2}{|c|}{ Additional undigested protein } \\
\hline & Control & $S F$ & $S C$ & (SF)-(Control) & (SC)-(Control) \\
\hline ASP & $1370 \pm 130 \mathrm{~A}$ & $3727 \pm 386 \mathrm{~B}$ & $3382 \pm 528 \mathrm{~B}$ & 18.60 & 18.25 \\
\hline THR & $1233 \pm 90 \mathrm{~A}$ & $1751 \pm 163 \mathrm{~B}$ & $1721 \pm 144 \mathrm{~B}$ & 4.09 & 4.43 \\
\hline SER & $986 \pm 84$ & $1513 \pm 140$ & $1468 \pm 193$ & 4.16 & 4.37 \\
\hline GLU & $2860 \pm 488 \mathrm{~A}$ & $5836 \pm 753 \mathrm{~B}$ & $6147 \pm 1338 \mathrm{~B}$ & 23.49 & 29.82 \\
\hline PRO & $928 \pm 72$ & $1627 \pm 236$ & $1592 \pm 261$ & 5.52 & 6.02 \\
\hline GLY & $782 \pm 71 \mathrm{~A}$ & $1554 \pm 241 B$ & $1447 \pm 176 \mathrm{~B}$ & 6.09 & 6.03 \\
\hline ALA & $894 \pm 115 \mathrm{~A}$ & $1462 \pm 232 B$ & $1235 \pm \quad 87 \mathrm{AB}$ & 4.48 & 3.09 \\
\hline CYS & $499 \pm 64 \mathrm{~A}$ & $787 \pm 86 \mathrm{~B}$ & $768 \pm 122 \mathrm{~B}$ & 2.27 & 2.44 \\
\hline VAL & $936 \pm 85$ & $1482 \pm 208$ & $1373 \pm 100$ & 4.31 & 3.96 \\
\hline MET & $222 \pm 35$ & $333 \pm 44$ & $294 \pm \quad 28$ & 0.88 & 0.65 \\
\hline ILE & $538 \pm 44 \mathrm{~A}$ & $1008 \pm 156 \mathrm{~B}$ & $870 \pm 62 \mathrm{AB}$ & 3.71 & 3.01 \\
\hline LEU & $1007 \pm 96 \mathrm{~A}$ & $1872 \pm 246 \mathrm{~B}$ & $1615 \pm 118 \mathrm{AB}$ & 6.83 & 5.52 \\
\hline TYR & $440 \pm 44 \mathrm{~A}$ & $703 \pm 64 \mathrm{~B}$ & $677 \pm 65 \mathrm{~B}$ & 2.08 & 2.15 \\
\hline PHE & $524 \pm 58 \mathrm{~A}$ & $1056 \pm 177 \mathrm{~B}$ & $855 \pm 72 \mathrm{AB}$ & 4.20 & 3.00 \\
\hline HIS & $307 \pm 32 \mathrm{~A}$ & $574 \pm 65 B$ & $546 \pm 71 \mathrm{~B}$ & 2.11 & 2.17 \\
\hline LYS & $1187 \pm 120$ & $1732 \pm 241$ & $1543 \pm 143$ & 4.30 & 3.23 \\
\hline ARG & $466+38 \mathrm{~A}$ & $831 \pm 82 \mathrm{~B}$ & $670 \pm \quad 44 \mathrm{AB}$ & 2.88 & 1.85 \\
\hline
\end{tabular}

Control diet: skim milk powder; SF diet: skim milk powder mixed with soyabean flour (50:50 on a CP basis); SC diet: skim milk powder mixed with soyabean protein concentrate (50:50 on a CP basis); means with different letters are statistically different $(P<0.05)$. 
ucts (Guilloteau et al, 1986; Khorasani et al, 1989; Nunes do Prado et al, 1989). However, $\mathrm{N}$ digestibility for the control diet was lower than that usually obtained with diets of similar composition containing European skim milk powder (Van Hellemond and Van Weerden, 1973; Guilloteau and Toullec, 1980; Guilloteau et al, 1986; Nunes do Prado et al, 1989; Bush et al, 1992). In contrast, our values for the control diet agreed with results recorded for North American skim milk powder (Khorasani et al, 1989; Petit et al, 1989). In the present experiment, the control diet contained $4.8 \mathrm{mg}$ soluble $\mathrm{N} / \mathrm{g}$ skim milk powder. This value, $<6 \mathrm{mg}$, indicated that the skim milk powder was "medium heated" and not "low heated". Gastric emptying of the same control diet was found to be faster than usual (Caugant et al, unpublished results). All these observations indicated that the skim milk powder used in the present experiment was not of high quality, which could have had a negative influence on digestibility (Toullec et al, 1978).

The 3 diets used in the present experiment were prepared with the same batch of fat premix, thus enabling comparison of the 3 diets despite the lower quality of the skim milk powder. Assuming that the apparent digestibility of milk $N$ was the same in the 3 diets $(0.90)$, the values calculated for soyabean $\mathrm{N}$ were 0.80 and 0.84 with the SF and SC diets, respectively. These values were lower than those obtained by Nunes do Prado et al (1989) for a soyabean isolate $(0.91)$ which provided $73.5 \%$ of the total protein of the diet. The digestibility of $\mathrm{N}$ of the soyabean protein concentrate was close to that of spring raw pea (0.83) (Bush et al, 1992), but lower than that of another soyabean protein concentrate prepared according to a similar process $(0.90)$ (Guilloteau et al, 1986). Khorasani et al (1989) found poor ileal digestibilities for diets in which 40 and $60 \%$ of protein was supplied by soyabean flour $(0.76$ and 0.73 , respectively). The higher value recorded in this experiment for soyabean flour suggested that the treatments had resulted in a better denaturation of the antinutritional factors. The fæcal N digestibility calculated for other batches of soyabean flour and of soyabean concentrate used in the present experiment were found to be 0.66 and 0.81, respectively (Lallès et al, 1991), when incorporated at $58 \%$ (on a crude protein basis). Since the ileal digestibility is usually lower than the fæcal digestibility, it appears that the batches used here had a better quality, especially soyabean flour. Therefore, large variations occur not only between soyabean products resulting from different processes, as can be expected, but also between different batches of commercial products. These variations are more important than those recorded for the skim milk powder. However, if they are not due to chance, they are positive since they result in a better quality and suggest that improvements are still possible.

The lower percentage of AAN in digesta compared to the diet was due to the higher content of hexosamines and urea, which are abundant in the digestive secretions and desquamated cells (Combe et al, 1980; Souffrant, 1991). The lower apparent digestibility of most AA with the SF and SC diets compared with the control diet agrees with results obtained by other workers with milk substitutes containing nonmilk proteins such as bacteria (Guilloteau et al, 1980; Sedgman et al, 1985), fish, soyabean (Guilloteau et al, 1986; Nunes do Prado et al, 1989) or pea (Bush et al, 1992). The apparent digestibilities of threonine, glycine and especially cystine were much lower, while those of methionine (and arginine with the soyabean-containing diets) were higher than the mean value. The low apparent digestibility of threonine and glycine with all diets may be due to the high content of these amino acids in endogenous protein (Sauer et al, 1977; Guil- 
loteau et al, 1986). Differences in AA digestibilities of SF and SC diets were generally small, attesting to the fact that the treatment used to prepare SF had largely improved its nutritional value.

The true digestibility of AA from soyabean flour and soyabean protein concentrate was calculated assuming that the true digestibility of total milk AA was complete and that the endogenous fraction was similar with the 3 diets (table III). The differences in true digestibilities between the 2 soyabean products were small. Among the essential AA, cystine and threonine were the least digestible with both the flour and the concentrate. That appears to be a characteristic of most soyabean products (Guilloteau et al, 1986; Nunes do Prado et al, 1989) and other legumes such as pea (Bush et al, 1992). It could be partially due to an increased loss of endogenous protein (Guilloteau et al, 1986).

As expected, when calves were fed the control diet, the AA composition of digesta was very different from that of the whole diet, bacteria or endogenous protein. The theoretical mixture of endogenous and bacterial proteins closest to the control digesta was 62 and $38 \%$. However, the $\chi^{2}$ distance between this mixture and the control digesta was still high (71), attesting to the fact that this model was not satisfactory. The theoretical mixture of $54 \%$ endogenous protein, $21 \%$ bacteria and $25 \%$ control diet was more relevant $\left(\chi^{2}=51\right)$, suggesting that milk protein could be present in the control digesta. However, the control digesta was much more similar to those previously obtained with European skim milk powders (Guilloteau et al, 1986; Nunes do Prado et al, 1989; Bush et al, 1992), as well as to that of the common mixture of endogenous and bacterial proteins (MEBP) escaping digestion in the small intestine (Guilloteau et al, 1986), in calves given diets based on milk, fish or soyabean protein $\left(20 \leq \chi^{2} \leq 27\right)$. The the- oretical mixture of MEBP and control diet which showed the best fit with the control digesta contained only $9 \%$ of the control diet and was not much closer to the control digesta than MEBP alone $\left(\chi^{2}=21\right.$ instead of 23). Similar trends were observed for the theoretical mixtures of control diet and the control digesta previously obtained. Therefore, the lower apparent digestibilities of $A A$ in the present experiment appeared to be more due to increased losses of endogenous and bacterial proteins than to an incomplete digestion of dietary protein. However, the presence, in the control digesta, of dietary fractions having an $A A$ composition different from that of the whole milk protein cannot be excluded on the basis of these observations. Particularly, the high concentration of lysine in the digesta could reflect a decreased availability of this $A A$.

The replacement of $50 \%$ milk protein by soyabean proteins induced changes in the $A A$ composition of ileal digesta, with no pronounced differences between the SF and the SC digesta. Using antibodies directed against their native forms, immunoreactive glycinin, $\alpha$ - and $\beta$-conglycinins were found in the SF digesta in amounts equivalent to 10,1 and $2 \%$ of intake, respectively (Tukur et al, unpublished results). With the SC diet, immunoreactive $\alpha$ conglycinin was also present in the digesta, but not glycinin and $\beta$-conglycinin. This was to be expected, since glycinin and $\beta$ conglycinin were entirely denatured in the concentrate. Theoretical mixtures of the control digesta and dietary soyabean which minimized the $\chi^{2}$ distances were 73 and $27 \%$ or 82 and $18 \%$ for the SF or SC digesta, respectively (table IV). However, the $\chi^{2}$ distances between these mixtures and digesta were still insufficiently low (43 and 53 , respectively) to consider these models as being satisfactory representations of undigested protein. Therefore, the immunoreactive glycinin and conglycinins 
found in the digesta were probably either partially digested fractions or accompanied by such fractions.

The AA composition of the additional undigested fractions obtained with the SF and SC diets, relative to the control diet, suggested that some particular soyabean protein fractions were not entirely digested in the small intestine, as observed by Guilloteau et al (1986) for an ethanol-treated soyabean concentrate. This fraction might have an AA composition different from that of the whole protein and therefore from that of the diet. The digesta obtained with the SF and SC diets and the additional undigested fractions, relative to the control diet, were rich in aspartic and glutamic acids as observed by Guilloteau et al (1986) with diets containing soyabean protein. Moreira et al (1979) determined AA composition of 10 polypeptides isolated from glycinin; among these, acid subunits $A 1$, $A 2, A 3$ and $A 4$ have a high content of aspartic and glutamic acids, although not as high as the additional undigested fractions. Theoretical mixtures of digesta obtained with the control diet and of subunit A1 which minimized the $\chi^{2}$ distance were 74 and $26 \%$ for the SF digesta $\left(\chi^{2}=39\right)$ and 76 and $24 \%$ for the SC digesta $\left(\chi^{2}=\right.$ 41). Therefore, A1 polypeptide might constitute an important part of the soyabean protein fractions escaping digestion in the small intestine. However, the levels of some AA in this subunit were different from those observed in the additional undigested fraction; for example, the arginine content was $6.9 \%$ in the subunit and $<3 \%$ in the additional undigested protein. Presumably, particular fractions of this subunit rather than the intact polypeptide may escape digestion in the intestine. Moreover, small parts of the additional undigested protein could be of endogenous and bacterial origin.

In a previous study (Caugant et al, unpublished results), it was observed that the flow of total and protein $\mathrm{N}$ into the duodenum was higher during the first $2 \mathrm{~h}$ following the meal with the SF and SC diets than with the control diet. Moreover, soyabean protein was less hydrolyzed than milk protein in the abomasum, in agreement with its higher resistance to gastric enzymes in vitro (Jenkins et al, 1980). Therefore, soyabean protein entered the intestine in larger amounts and sooner after the meal than milk protein, which could influence the rate of proteolysis by pancreatic and intestinal enzymes and the subsequent absorption of the AA (Matthews, 1975).

\section{CONCLUSION}

The replacement of $50 \%$ milk protein by soyabean protein resulted in a decrease in the apparent ileal digestibilities of DM, organic matter, $\mathrm{N}$ and $\mathrm{AA}$. Particular fractions of soyabean proteins (glycinin), rich in aspartic and glutamic acids, appeared to partially escape digestion in the small intestine. The digestibilities of nitrogen and AA were only slightly lower with the soyabean flour than with the concentrate. Compared to the results of previous experiments, the values obtained in this study were higher than with other batches of the same products, but lower than with another alcohol-treated concentrate and with partially hydrolyzed isolate. Therefore, the nutritional value of commercial soyabean products, especially prepared for the replacement of milk protein, may vary not only with the manufacturing process but also with time. Moveover, the preruminant calf appears to be a sensitive model to study protein quality.

\section{ACKNOWLEDGMENTS}

The authors wish to thank $S$ Boussion and $G$ Savary for assistance with the daily care of the 
calves. This work was supported by a grant from France-Québec Cooperation in Biotechnology, a grant from the Ministère de la Recherche et de la Technologie (France), and a grant from Lactel (Québec) and the Union Laitière Normande (France).

\section{REFERENCES}

Akinyele IO, Harshbarger KE (1983) Performance of young calves fed soybean protein replacers. J Dairy Sci 66, 825-832

Bush RS, Toullec R, Caugant I, Guilloteau P (1992) Effects of raw pea flour on nutrient digestibility and immune responses in the preruminant calf. J Dainy Sci 75, 3539-3552

Campos OF, Huber JT, Bergen WG (1982) Partial substitution of milk protein with spray-dried fish solubles or soy protein concentrates in calf milk replacers. J Dairy Sci 65, 1240-1246

Caugant I, Petit HV, Charbonneau R, Savoie L, Toullec R, Thirouin S, Yvon M (1992) In vivo and in vitro gastric emptying of milk replacers containing whey proteins. J Dairy Sci 75 , 847-856

Combe E (1976) Influence de la microflore sur la composition en acides aminés des fèces des agneaux. $C R$ Soc Biol 170, 787-793

Combe E, Patureau-Mirand P, Bayle G, Pion R (1980) Influence de l'aliment et de la microflore sur la teneur en sucres aminés des contenus digestifs et des fèces chez le rat, l'agneau et le veau préruminant. Reprod Nutr Dev 20, 1707-1715

Dawson DP, Morrill JL, Reddy PG, Minocha HC, Ramsey HA (1988) Soy protein concentrate and heated soy flours as protein sources in milk replacer for preruminant calves. $J$ Dairy Sci 71, 1301-1309

Di Pietro CM, Liener E (1989) Heat inactivation of the Kunitz and Bowman-Birk soybean protease inhibitors. J Agric Food Chem 37, 39-44

Duvaux C, Guilloteau P, Toullec R, Sissons JW (1990) A new method of estimating the proportions of different proteins in a mixture using amino acid profiles: application to undigested proteins in the preruminant calf. Ann Zootech 39, 9-18

Grongnet JF, Patureau-Mirand P, Toullec R, Prugnaud $J(1981)$ Utilisation des protéines du lait et du lactosérum par le jeune veau préruminant. Influence de l'âge et de la dénaturation des protéines du lactosérum. Ann Zootech 30, 443-464

Guilloteau P, Toullec R (1980) Digestion of milk protein and methanol-grown bacteria protein in the preruminant calf. I Kinetics and balance in the terminal small intestine and faecal balance. Reprod Nutr Dev 20, 601-613

Guilloteau P, Patureau-Mirand P, Toullec R, Prugnaud $J(1980)$ Digestion of milk protein and methanol-grown bacteria protein in the preruminant calf. II. Amino acid composition of ileal digesta and faeces and blood levels of free amino acids. Reprod Nutr Dev 20, 615-629

Guilloteau $P$, Sauvant $D$, Patureau-Mirand $P$ (1983) Methods of comparing amino acid composition of proteins: application to undigested proteins in the preruminant calf. Ann Nutr Metab 27, 457-469

Guilloteau P, Toullec R, Grongnet JF, PatureauMirand $P$, Prugnaud $J(1986)$ Digestion of milk, fish and soyabean protein in the preruminant calf: flow of digesta, apparent digestibility at the end of the ileum and amino acid composition of ileal digesta. Br J Nutr 55, 571-592

Huisman J, Jansman AJM (1991) Dietary effects and some analytical aspects of antinutritional factors in peas (Pisum sativum), common beans (Phaseolus vulgaris) and soyabeans (Glycine max $L$ ) in monogastric farm animals. A literature review. Nutr Abstr Rev (Ser B) 61, 901-921

Jenkins KJ, Mahadevan S, Emmons DB (1980) Susceptibility of proteins used in calf milk replacers to hydrolysis by various proteolytic enzymes. Can J Anim Sci 60, 907-914

Khorasani GR, Sauer WC, Maenhout F, Kennelly JJ (1989) Substitution of milk protein with soy flour or meat-solubles in calf milk replacers. Can J Anim Sci 69, 373-382

Kilshaw PJ, Sissons JW (1979) Gastrointestinal allergy to soyabean protein in preruminant calves. Allergenic constituents of soyabean products. Res Vet Sci27, 366-371

Koshiyama I (1968) Chemical and physical properties of a $7 S$ protein in soybean globulins. Cereal Chem 45, 394-404

Lallès JP, Roger L, Toullec R (1991) Antigenicity and digestive utilization of soyabean protein by veal calves. In: Protein Metabolism and Nutrition (Eggum BO, Boisen S, Borting C, Danfaer A, Hvelplund T, eds) EAAP Publ No $59,222-224$ 
Mason VC (1979) The quantitative importance of bacterial residues in the non-dietary fæcal nitrogen of sheep. I. Methodology studies. Z Tierphysiol Tierernähr Futtermittelkd 41, 131-139

Mason VC, Just A, Bech-Anderens S (1976) Bacterial activity in the hindgut of pigs. 2 Its influence on the apparent digestibility of nitrogen and amino acids. $Z$ Tierphysiol Tierernähr Futtermittelkd 36, 310-324

Matthews DM (1975) Intestinal absorption of peptides. Physiol Rev 55, 537-608

Moreira MA, Hermodson MA, Larkins BA, Nielsen NC (1979) Partial characterization of the acidic and basic polypeptides of glycinin. J Biol Chem 254, 9921-9926

Nitsan Z, Volcani R, Gordin S, Hasdai A (1971) Growth and nutrient utilization by calves fed milk replacers containing milk or soybean protein concentrate heated to various degrees. J Dairy Sci 54, 1294-1299

Nunes do Prado I, Toullec R, Guilloteau P, Guéguen J (1989) Digestion des protéines de pois et de soja chez le veau préruminant. II. Digestibilité apparente à la fin de l'iléon et du tube digestif. Reprod Nutr Dev 29, 425-439

Okubo K, Asano M, Shibasaki I (1969) On basic subunits dissociated from $C$ (11S) components of soybean proteins with urea. Agric Biol Chem 33, 463-465

Petit HV, Ivan M, Brisson GJ (1989) Digestibility measured by fecal and ileal collection in preruminant calves fed a clotting or a nonclotting milk replacer. J Dairy Sci 72, 123-128

Prugnaud J, Pion R (1976) Dosage des acides aminés dans les aliments. Journ Biochimie (Paris) 1-22
Sauer WC, Stothers SC, Parker RJ (1977) Apparent and true availabilities of amino acids in wheat and milling by-products for growing pigs. Can J Anim Sci 57, 775-784

Sedgman CA, Roy JHB, Thomas J, Stobo IJF, Ganderton $P$ (1985) Digestion, absorption and utilization of single-cell protein by the preruminant calf. The true digestibility of milk and bacterial protein and the apparent digestibility and utilization of their constituent amino acids. Br J Nutr 54, 219-244

Silva AG, Huber JT, De Gregorio RM (1986) Influence of substituting two types of soybean protein for milk protein on gain utilization of milk replacers in calves. J Dainy Sci 69, $172-$ 180

Sissons JW, Smith RH, Hewitt D (1979) The effect of giving feeds containing soyabean meal treated or extracted with ethanol on digestive processes in the preruminant calf. $\mathrm{Br}$ J Nutr 42, 477-485

Souffrant WB (1991) Endogenous nitrogen losses during digestion in pigs. In: Digestive Physiology in Pigs (Verstegen MWA, Huisman J, Den Hartog LA, ed) Pudoc, Wageningen, $147-166$

Toullec R, Thivend P, Vermorel M, Guégnen L (1978) Chapitre 10 veaux: veau préruminant. In: Alimentation des Ruminants (Jarrige R, ed) INRA Publ, 245-295

Van Hellemond KK, Van Weerden EJ (1973) Milk protein substitutes in rations for veal calves. Proc Nutr Soc 32, 231-235

Williams VJ, Roy JHB, Gillies CM (1976) Milksubstitute diet composition and abomasal secretion in the calf. Br J Nutr 36, 317-335 